\title{
Sacrificing Judith
}

\author{
Anne-Mareike Wetter
}

\section{Introduction}

"Judith ... Isn't she the one who cut off that general's head?" is a common reaction when the name of this intriguing woman is mentioned. In order to save her hometown Bethulia, Jerusalem, and ultimately Israel as a whole from the threat of the advancing Assyrian army, the widow Judith enters the enemy camp, beguiles all the men present - including the captain, Holofernes - and eventually decapitates the latter as he lies on his bed, completely intoxicated. Back in Bethulia, she orders the Israelites to rout the stunned Assyrians and loot their camp. The final scene depicts Judith as the leader of a triumphal procession towards Jerusalem, where she and the people dedicate the spoils to God. Judith then returns to her former life as a chaste and pious widow.

So much for the plot of this apocryphal book, which is usually dated to the second half of the second century BCE. Although it is presented as 'history', the reader immediately notices the many anachronisms strewn throughout the text. These aberrations from 'real' history account for much of the book's ironic quality. Moreover, they suggest that something other than historiography was the main concern of its author.

One feature that strikes even the casual reader, is the preoccupation with ritual in the book. Sacrificial acts seem to mark the key points of the narrative. Virtually every action of Judith or other Israelites is accompanied by ritual performance. In addition to the conventional rites she engages in, Judith repeatedly takes an action out of its original context and, through verbal or other means, assigns it an added ritual and religious significance. It is this process of 'ritualization', rather than the conventional sacrifices that gives religion in the Book of Judith its intriguing and versatile quality.

Until recently, scholars' knowledge of ritual in general and of sacrifice in particular leaned heavily on a limited number of universal theories about these phenomena. All aimed at explaining ritual and sacrificial acts regardless of their particular geographical, religious, or social contexts. Unsurprisingly, over the past decades scrapes have appeared on the smooth surface of monolithic 
theories of ritual and sacrifice. Their designers were criticized for wanting too much and too little at the same time - too much, because they presented their concepts as theoretical panacea for widely disparate phenomena, and too little, because their definitions of ritual and sacrifice proved too narrow to analyze anything that fell outside their immediate scope. ${ }^{1}$ Eventually, new paradigms replaced those that had thus far determined most research in these areas: 1) universality was abandoned in favor of contextualization; 2) the assumed priority of myth over ritual made room for an interest in ritual on its own terms; 3) the notion of ritualization entered the discussion, bringing with it a new appreciation of the creative potential of ritual acts; and 4) definitions of sacrifice, which until that time had been rather static and had almost always included violence of some kind, made room for new, polythetic approaches to sacrifice.

The first point does not require much elaboration - instead of approaching ritual in general and sacrifice in particular as universal notions, scholars began to appreciate their unique quality and function in different cultural and social contexts.

The second and third point can both be linked to the work of Catherine Bell, although others certainly contributed to this paradigm shift as well. In Ritual Theory, Ritual Practice, Bell advocates an alternative, more action-oriented approach to those acts usually described as rituals. She insists that ritual not so much integrates separate or even opposing forces - for example, the beliefs held by society and the individual who has to conform to them - but rather creates a separation itself, namely between the sacred and the profane:

Viewed as practice, ritualization involves the very drawing, in and through the activity itself, of a privileged distinction between ways of acting, specifically between those acts being performed and those being contrasted, mimed, or implicated somehow. (...) Ritualization gives rise to (or creates) the sacred as such by virtue of its sheer differentiation from the profane. ${ }^{2}$

1 For a critical account of the development of ritual theory in general, see Catherine Bell, Ritual Theory, Ritual Practice (New York: Oxford Univ. Press, 1992). For the criticism voiced against at least some of the theories on sacrifice enumerated above, see David Janzen, The Social Meanings of Sacrifice in the Hebrew Bible. A Study of Four Writings (Berlin: De Gruyter, 2004), 78-81.

2 Bell, Ritual Theory, 90-91. 
This focus on ritualization as a creative process, not bound to pre-defined rules, opens up perspectives for a much broader notion of what qualifies as ritual(ization). For Bell, ritual is not a specific type of activity directed towards what an underlying myth or belief system defines as sacred. It is the act of ritualization itself that creates a sacred sphere or space and, even more importantly, imbues ordinary objects and events with new meaning and significance when placed within a specific context. This notion seems to illuminate many of Judith's actions, especially if we take some recent advances in the theory of sacrifice into account.

A relevant example of creative reconsideration of the nature and function of sacrifice can be found in the work of Kathryn McClymond. One of her contributions to the field is the insight that violence, bloodshed and actually killing may be significantly less central to many sacrificial practices than the dominant theories presuppose.

McClymond argues for the inclusion of a variety of other practices and substances, such as milk, oil anointments, and flowers. She states:

'[S]acrifice' as an authoritative concept is often appropriated within streams of religious communities to authorize practices other than traditional sacrifice. Sacrifice becomes a metaphor for other activity. ${ }^{3}$

This mechanism of 'metaphorization' contributes both to the "persistence of sacrifice as an authoritative category"4 even in the absence of the means to perform traditional sacrificial acts, and to the legitimation of the alternative practices.

Often the process at work here can be described as the "interiorization of ritual", a term for which McClymond refers to the Israeli religion scientist Yael Bentor. Sacrifice along this line,

may pertain to a mental performance of the ritual; to the replacement of the ritual with a continuous process of life, such as breathing or eating; to a particular way of life, such as renunciation; to an actual performance with an inner interpretation; to the replacement of the external ritual with an internal one, and so forth. ${ }^{5}$

3 Kathryn McClymond, Beyond Sacred Violence. A Comparative Study of Sacrifice (Baltimore: Johns Hopkins, 2008), 3 .

4 McClymond, Beyond Sacred Violence, 155.

5 Yael Bentor, "Interiorized Fire Rituals in India and Tibet", Journal of the American Oriental Society, 120 (2000): 594-613 (594). 
McClymond mentions prayer and asceticism as examples of practices falling into this category of metaphorical, or interiorized, sacrifice - two examples that will turn out to be highly significant for the study of Judith.

Turning to Judith, within the framework of ritualization, many actions and attitudes in at least three different areas can be construed as sacrificial: first of all, in Judith's general lifestyle before she even comes into action on behalf of her community; second, in the prayers Judith offers both before and after the execution of her plans; and third, in the actions Judith undertakes to rescue the Israelites, which can be read as an appropriation of the biblical concept of 'War of YHWH'.

In the Book of Judith, the omnipresence of ritual is striking. Some of the ritual acts fall within the scope of conventional Temple sacrifice. Facing the threat of annihilation, the Israelites engage in what looks like an overkill of prayer, mourning rituals, and sacrifices (4:8-15), adorning even their livestock with sackcloth (4:10). Interestingly, the rituals in this case come after the more practical preparations against the Assyrian threat, like fortifying the border villages, laying up provisions and devising a defense strategy (4:4-7). God's response is ambiguous - he "heard their voices and looked on their misery" (4:13), but does not take action. If do ut des is the rationale behind these sacrifices, something has clearly gone awry.

Unlike the religious rulers and the rest of the people, who plunge into official ritual and sacrificial acts but nonetheless seem to uphold the maxim "erst das Fressen, dann die Moral", 6 Judith has organized her entire life as a continuous sequence of ritual performances. She prefers a tent on the roof of her house to the comforts of the house itself; she wears her widow's attire far beyond the regular period of mourning, and she fasts almost continually (8:5-6). Bentor's words about the different shapes of interiorized sacrifice - especially a lifestyle marked by renunciation - come to mind. ${ }^{7}$

The text appears ambiguous about the rationale underlying Judith's ascetic lifestyle. On the one hand, her widowhood is stressed ("Judith had been widowed in her house for three years and four months", 8:4; "she fasted all the days of her widowhood", 8:5), implying that her lifestyle is an expression of prolonged mourning. On the other hand, verse 8 emphasizes her piety: "There

6 German saying based on a line by Bertold Brecht's Dreigroschenoper.

7 Bentor, Fire rituals, 594. 
was none who spoke evil of her, for she feared God greatly." This evaluation suggests that Judith has devoted her life to the service of God, and that widowhood has little to do with her choice of lifestyle. I suggest that the ambiguity concerning Judith's motivations serves a purpose. The text seems to imply that Judith presents the perfect candidate for the role she is about to take on. In order for her to do what she does - leave the village on her own, engage in close contact with male adversaries, and maintain a reputation that is above all reproach - she must be a widow, that is, no longer bound by the restraints applying to virgins or married women, yet still visibly attached to her deceased husband. At the same time, it has to be clear that her first priority is to serve God. Through her ascetic lifestyle, she removes herself from the mundane concerns occupying the rest of the people, and instead maintains close contact with a more spiritual reality. Consequently, she can speak with authority about God's purposes with Israel.

Initially, Judith seems to be so absorbed in her religious duties that the distress of her people hardly touches her. It is only when the people confront their leaders with an ultimatum - "if God does not deliver us within five days, we will submit to the Assyrians" - that she enters the narrative. Her first action consists of a rebuke of the elders that almost takes the shape of a sermon. Judith has her own ideas about how the history of Israel should be interpreted, and knows that the plans of the God she so "greatly fears" (8:8) cannot be fathomed, nor can he himself be put to the test. Intriguingly, she herself seems to know exactly what God is planning to do: without any hesitation, she promises the elders divine deliverance through her hand (8:32-34).

Once the elders have left, Judith starts to pray - not quite coincidentally, one may assume, at the same time as the "incense offers were being brought to the house of God in Jerusalem" (9:1). According to the biblical record, these incense offers were installed as part of the worship of Israel during its foundational period as the people of God: the desert wanderings. ${ }^{8}$ Judith 9:1 suggests that there is a continuous line from the divine command spoken to Moses in Exodus to the practice in Judith's time, interrupted only by the catastrophe of the Exile. The timing of Judith's prayer thus functions to place her words in the context of the ritual routine of Israel. More specifically, it suggests that Judith's words are not just a spontaneous expression of her own individual thoughts and feelings, but must be interpreted within the framework of official worship. What perhaps would not have counted as official worship by itself (after all, a prayer composed and uttered by a widow on the roof of her private home hardly qualifies as such), is legitimized and ritualized by means of the crucial

8 Exod. 30:1-8; 40:26-27. 
side remark about its timing. And by extension, Judith, the ritual actor, effectively joins the ranks of the priests as they address God in their daily prayers. I suggest that we see at work here the mechanism McClymond describes as 'metaphorization of sacrifice'. Based on the official regulations regarding incense offerings, Judith is the wrong person (neither a Levite nor a man) in the wrong place (on a roof in a border city, not in the Temple of Jerusalem). Conventional sacrifice, therefore, is not an option available to her. However, metaphorized or interiorized sacrifice $i$ s. Through this process, Judith as the sacrificial actor and her prayer as the object offered are legitimized, while simultaneously the legitimacy of the official sacrificial cult is affirmed. ${ }^{9}$

\section{1 'Holy' War and 'Holy' Warrior}

Judith's prayer is intriguing, not just as a ritual per se, but also because it contains several instances of ritualization on the level of content. Initially, quite mundane actions and events are imbued with religious significance through the way in which Judith connects them with each other and with her own situation. Taking the rape of Dinah and the subsequent revenge of her brother Simeon on the Shechemites as a paradigm for her own planned actions, Judith construes both Simeon's and her own deed as instances of 'Wars of YHWH', which are acts of aggression that God not only condones but actually instigates. According to Judith, and in deviation from the genotext in Genesis 34, it is God who puts the sword in Simeon's hand (Jth. 9:3; Gen. 34:25) and ultimately causes the downfall of the Shechemites (Jth. 9:4; Gen. 34:26-29). Besides, Judith considers the threat of the Assyrians primarily a threat against the Temple: "They plan to disgrace the temple where you are worshiped and to chop off the corners of your altar with swords" (Jth. 9:8) She thereby takes a military invasion out of its original context (an attempt to subdue the population of a rebellious province) and inserts it into the context of God's struggles with his human challengers.

Judith has often been seen as a female warrior, ${ }^{10}$ and in some cases, a holy warrior as well. I will develop the characterization as holy warrior based not

Interestingly, Judith is not the only one whose prayer is to be counted as incense offering. In a psalm attributed to David, we read: "Let my prayer be established as incense before you, the lifting of my hands as the evening sacrifice" (Psalm 141:2/140:2, LXX). Apparently, the substitution of sacrifice by prayer was no new invention - what is new in Judith, perhaps, is the application of this concept to a woman.

10 Thus, e.g., Craghan: "The beauty process in 10:2-4 is really a disguise. Judith is actually the female warrior $(. .$.$) who has mapped out her military strategy and concealed her$ weapon, viz., her beauty. Thus the female sets out to rescue the male, using the most 
only on Judith's actions in the Assyrian camp, but also on the prayers and practices framing them. The concept of 'holy war' is well-attested in other biblical sources, notably the beginning of the Deuteronomistic history. Perhaps a more appropriate and less suggestive term is 'War of $\mathrm{YHWH}$ ', for God is consistently portrayed as the instigator of, and main actor during, these battles. Patrick Miller, for example, describes warfare in early Israel as a synergism of divine and human efforts. ${ }^{11}$ Consequently, a War of YHWH was a matter of ritual as well as warfare: it was preceded by oracle inquiry, conducted either by a priest or the military leader prior to battle in order to assess the chances of victory, and the ritual purification of the camp and the warriors. Miller goes on to claim: "Most important of all, however, was the practice of herem, the devotion of the spoils - both men and property - to Yahweh."12 Israel was not to fight for its own economic advancement, but exclusively for the honor of God. ${ }^{13}$

All of this suggests that those participating in a War of God were expected to engage in their martial activities as a religious service. And perhaps the notion of (self-)sacrifice is not too far-fetched in this context. Susan Thistlethwaite, in any case, summarizes the requirements for a holy warrior as follows:

Warriors who had not a singleness of heart were sent home (Deut. 20:5-9). Only warriors who looked on war making as sacrifice, who 'offered themselves willingly' (Judg. 5:2), could go. The full support of the priests and cult was behind the war (Deut. 20:2; 1 Sam. 10:1) and the warrior became a kind of holy person, a priest, in the war (1 Sam. 21:14; Isa 13:3). Ritual taboos regarding contact with a woman prior to battle apply (1 Sam. 21:4; 2 Sam. 11:11). ${ }^{14}$

Of course, in the original setting of pre-monarchic and monarchic Israel Thistlethwaite refers to, the confrontation with the enemy on the battlefield

effective weapon - beauty." See John F. Craghan, "Esther, Judith and Ruth: Paradigms for Human Liberation," Biblical Theology Bulletin 12 (1988): 11-19. Similarly, C. A. Moore argues: "Just as a soldier facing battle takes much care preparing himself and his arms, so our Female Warrior dressed herself with much deliberateness." See Carey A. Moore, Judith, The Anchor Bible, vol. 40 (New York: Garden City, 1985), 200.

11 Patrick D. Miller Jr., The Divine Warrior in Early Israel (Cambridge MA: Harvard University Press, 1973), 156 .

12 Miller, Divine Warrior, 157.

13 See also N. Lohfink, "hrm", in Theologisches Wörterbuch zum Alten Testament (eds G. J. Botterweck and H. Ringgren, Stuttgart: Kohlhammer, 1982), vol. III, 192-213.

14 Susan Brooks Thistlethwaite, "You May Enjoy the Spoil of Your Enemies. Rape as a Biblical Metaphor for War," Semeia 61 (1993): 67. 
would have been a male prerogative. ${ }^{15}$ Nevertheless, I suggest that Judith's performance of her rescue mission bears many resemblances to the practices and attitudes Miller and Thistlethwaite describe. Except from her sex, Judith qualifies as the ideal participant in a War of YнWH. She is not bound to her home by husband or children. Her sexual purity is unquestioned. She casts her own deeds within the framework of Israel's cultic life, taking on the double role of priest and warrior. And last but not least, her actions can be interpreted as a sacrifice on behalf of her people: she is willing to risk the integrity of her body and ultimately her life for the greater good.

The preparations Judith undertakes after having finished praying underline the ritual character of her actions. She takes off her sackcloth, bathes, anoints herself with oil, and puts on jewelry and festive clothes. Of course, the most common-sense reasoning behind this is the wish to "beguile every man who sets eyes on her" (10:4) - one of the most crucial conditions for her plan to succeed. Claudia Rakel, however, sees a religious significance too:

Stärker als die Tatsache, dass Judit sich schön macht und damit in der Tradition vieler biblischer Frauengestalten steht, stechen die Parallelen zwischen ihrer Kleidung und der priesterlichen Garderobe ins Auge. ${ }^{16}$

André LaCocque, on the other hand, suggests that Judith

adorns herself as a sacrificial victim. From now on the enemy's attention will be forced upon her instead of on the whole of Bethulia. She makes of herself a substitutive offering. ${ }^{17}$

Rakel and LaCocque obviously handle different approaches to Judith's preparations. Rakel casts her in the role of the priest, who enjoys the special protection of the deity, while LaCocque perceives in her the sacrificial victim, consciously leaving behind any kind of protection. But these two approaches may not be

\footnotetext{
15 The Hebrew Bible does record the deeds of some individual women who contributed decisively to the outcome of an armed conflict, e.g., Hagar (Josh. 6), and Deborah and Jael (Judg. 4).

16 Claudia Rakel, Judit - über Schönheit, Macht und Widerstand im Krieg. Eine feministischintertextuelle Lektüre (Berlin, New York: Walter de Gruyter, 2003), 131. (Translation: "Stronger than by the fact that Judith adorns herself and doing so ranges herself into the tradition of many outstanding women in the Bible, we are struck by the analogy between her clothing and the priestly attire").

17 André LaCocque, The Feminine Unconventional. Four Subversive Figures in Israel (Nottingham: Wipf \& Stock, 2005), 47.
} 
mutually exclusive, if we read Judith's mission as part of a War of God, and accept Thistlethwaite's claim that warriors "became a kind of holy person, a priest", and were simultaneously expected to "offer themselves willingly."18

It is clear that Judith is setting the actions she is about to take apart from her everyday life. She changes her location and her outfit, and in the next verse prepares a number of food items, which sharply contrast with her habit of fasting almost continually. This raises the question how the ritual-like demarcation between ordinary life and rescue mission can be interpreted. If ritualization is about the creation of a (religious) context that is set apart from more ordinary actions, ${ }^{19}$ then what, in this case, is the 'religious context', and what the 'ordinary'? What, if anything, can be read as 'sacrifice'? Is Judith indeed engaging in the ritual purification required of a holy warrior before entering battle? Or do her preparations, quite to the contrary, signify a departure from an everyday life that is characterized by a rigorous ritual routine - a routine that could be construed as the internalization of sacrificial practice - which she is willing to exchange for a worldlier lifestyle for the duration of her mission? Or would such a strict separation between 'ordinary' and 'religious' be based on false assumptions in the case of Judith's mission? Would it not be more fitting to speak of different, but nonetheless connected domains, in which Judith gives shape to her religious life with respect to the notion of sacrifice, albeit in different ways in both domains?

I suggest that the latter is the case. It is true that Judith's mission into the Assyrian camp is a temporary departure from her customary life of austerity and seclusion into a world of luxury, sensuality, and violence. Judith's life is acknowledged to be marked by great piety - it consists, as it were, of a continuous sequence of ritualizing, even sacrificial acts, and these acts create the overarching context within which all Judith's actions must be understood. This includes the excursion into the enemy camp, which is neither a sharp break from her normal life of piety, nor a ritual act which, through its extraordinary quality, would somehow devalue this life as ordinary in the sense of mundane. It is, rather, quite literally "out of the ordinary" - exceptional, but firmly rooted in Judith's daily practice of faith. Additionally, Judith's mission bears witness to how she persistently gives shape to her own ritual reality, a reality that is embedded in the myths and rituals of Israel, but reinvented in both a creative and autonomous way.

18 Thistlethwaite, Enjoy, 67.

19 Bell, Ritual, e.g. 90. 


\subsection{In the Enemy's Camp}

At least part of Judith's creativity is rooted in the many double entendres that will characterize the narrative from now on: acts and words which are perfectly comprehensible on a profane level gain a different or added significance if placed within the ritual context Judith creates wherever she goes.

A first incident worth noting is the encounter between Judith and the town elders and guardsmen at the city gate of Bethulia: "When they saw her, and how her face was changed, and how different her clothing was, they marveled greatly at her beauty ..." (Jth. 10:7). At first sight, it is Judith's physical attractiveness that is at stake here. But the change in Judith's appearance can be appreciated on another level too. Several readers have noted the parallels between Judith and Moses. ${ }^{20}$

I suggest that Jth. 10:7 contains another subtle allusion to the famous first leader of the Israelites. After all, Moses' appearance, too, was changed due to an encounter with God (Exod. 34:30, 35). And even though the vocabulary describing the reaction of the onlookers differs (thaumazo in the case of Judith, phobeo / eggizō in the case of Moses), I would claim that the parallel is at least implied: the change that has come over Judith is something more than dress and make-up can accomplish. As was the case with Moses, some of the glory of God seems to have rubbed off on her. ${ }^{21}$

Naturally, the Assyrians see only the extremely attractive woman approaching them. Even though they do not strictly need her assistance to triumph over the Israelites - after all, Bethulia is on the verge of surrender - they are eager to oblige when she demands to speak to their captain. Holofernes, too, is immediately taken in by Judith's looks and promises. And quite contrary to his scornful treatment of the religion of the other peoples he has subdued, he shows an almost touching concern for Judith's ritual purity, wondering what she will eat once her own provisions have run out (12:2). Judith, however, promises him victory before that will be the case. On a profane level, then, the food Judith had brought to the Assyrian camp with her is part of her performance, underlining how swiftly she will lead Holofernes to victory. On another level, however, it spans a bridge between her pious life in Bethulia and her mission in

20 Jan Willem van Henten, "Judith as a Female Moses: Judith 7-13 in the Light of Exodus 17, Numbers 20 and Deuteronomy 33:8-11," in Reflections on Theology and Gender (eds Athalya Brenner and Fokkelien van Dijk-Hemmes, Kampen: Kok-Pharos, 1994), 33-48.

21 Of course, whereas appearance in the sense of attractiveness never seems to have played a role for Moses' acceptance as divinely ordained leader, the 'radiance' of Judith's looks is more ambiguous. She is always in the first place a beautiful woman, and only those with very sharp eyes will see more in her than seductive curves and appealing facial features. 
the Assyrian camp. Her dress and location may change, but no Assyrian food, and certainly no Assyrian man will enter her body. Judith keeps herself apart sacred - from anything that could dilute the sharp border between her body and the bodies of the Assyrians.

Judith's nightly excursions from the camp also serve a double purpose. On a practical level, they create a precedent, so that her flight with Holofernes' head in her bag is not immediately noticed as such. But they also serve to underline the separation between Judith and the Assyrians - Judith uses her outings to wash herself clean from any traces of contact with the enemy - and to frame her actions within the ritual context that has determined her entire life up to this point.

Even during the fatal drinking bout, Judith sticks to her own provisions, underlining the boundary between her and the men surrounding her. Once Judith is alone with Holofernes, the most (in-)famous scene of the narrative unfolds. Compared to the elaborate and lengthy preparations of the circumstances that have led up to this event, the scene is surprisingly short. In only eight verses, Judith prays for strength (13:4-5), grasps Holofernes' sword (13:6), prays again (13:7), severs his head (13:8), takes the head and the canopy of the bed to her maidservant (13:9), and, together with her maidservant, returns to Bethulia to announce that "with us, God, our God, has worked power again in Israel, and might against the enemies" (13:11). The visual arts seem to glory in this scene - apparently, the perceived paradox between the beautiful, pious widow and the truculence of Holofernes' assassination speaks to the imagination. In some of the paintings, a sacrificial interpretation seems to suggest itself. ${ }^{22}$ Holofernes lies on his bed as though it were an altar, and the streams of blood from his neck remind one of the blood of the animal victims so central for Temple sacrifice. Is it possible, then, to read Judith's murder of Holofernes as related to the animal sacrifices offered to God on a regular basis? Does Holofernes, for example, perform the function of a Girardian scapegoat, who has to die in order for peace to be restored? Perhaps. Nevertheless, the wording of the Greek text suggests otherwise. Judith 13:8 reads:

And she struck his neck twice with (all) her strength, and took his head from him.

The keywords in this verse - patassō (strike), trachèlon (neck), and perhaps also ischus (strength) are not at all reminiscent of cultic sacrifice. Rather, they seem to point again to the concept of the War of God and of God's dealings

See, e.g., the works by Caravaggio and Artemisia Gentileschi. 
with those who do not submit to his rule. The neck, especially when accompanied by the attribute sklèros (stiff, stubborn) or the verbal form sklèrunō (make stubborn, harden) is the body part that symbolizes precisely this refusal to bow to God's authority. ${ }^{23}$ More than once, God's response is to strike (patassō) the offender (Israelite or otherwise) with hunger, disease, or just straightforward death. ${ }^{24}$ Of course, the one who strikes does not have to be divine; the verb often describes inter-human aggression as well. ${ }^{25}$ An interesting example is the struggle between David and Goliath, where the same word as in Judith 13:8 is used to describe David's attack on the giant. Last but not least, in some cases, God explicitly commands his people to strike, as in Deut. 7:1-2:

And the Lord your God brings you into the land, into which you go to possess it, and removes great nations before you [...], and when the Lord delivers them into your hands, then you must strike them; you must destroy them completely: you must not enter into a covenant with them or have compassion on them.

I would suggest that the context provided here and in similar verses offers a more plausible parallel for the scene in Judith 13. Holofernes is no lamb being led to ritual slaughter, but an enemy whom God has given into Judith's hands. This is not to say that there is no ritual or even sacrificial undercurrent to this scene. It is the most decisive moment of Judith's mission as God's warrior. As such, it partakes in the sacrificial character of every one of God's wars. True to his command in Deut. 7:2, Judith makes sure that her enemy is destroyed completely.

\subsection{The Offering of the Cursed Thing}

A final hint that it is the context of 'Holy War' that imparts meaning to Judith's actions can be found in the concluding scenes of the narrative. Having arrived at Jerusalem, the first thing the people and Judith do is offer their "whole burnt offering, and their voluntary offerings, and their gifts" (Jth. 16:18). In addition, in verse 19,

Judith dedicated (anethèken) all the equipment of Holofernes, which the people had given her, and the canopy, which she herself had taken from his bed, she gave to God as a cursed thing (anathèma).

\footnotetext{
23 See, e.g., Deut. 10:16; 31:27; 2 Chron. 30:8; 36:13; Neh. 9:16-17.

24 E.g., Exod. 3:20; 9:15; Deut. 28:22, 27, 35.

25 E.g., Deut. 19:4, 6, 11; Josh. 13:12, 21; 19:47; Judg. 1:5, 8, 10, 12, 25; 1 Sam. 17:49; $18: 7$.
} 
Here, another detail that I had tentatively interpreted as hinting in the direction of a War of God, is confirmed by the text itself. In most cases, the Hebrew equivalent of anathèma is herem (devoted thing, devotion or ban), a terminus technicus from the semantic field of the War of YHWH. ${ }^{26}$ The precise meaning of the term is debated, ranging from violent interpretations ('destroy completely') to more moderate proposals ('devote to God', 'separate from society'). ${ }^{27}$ What counts here is that by using the specific term anathèma, the author places Judith's actions within the context of Holy War, known to him from the literary conventions of other biblical sources.

If Judith's role as holy warrior had not yet been firmly established before, this is established now. Moreover, her motivations for taking the canopy of Holofernes' bed (Jth. 13:9) become clear. At the time, this action had seemed rather nonsensical - in any case, carrying a large piece of cloth would have increased the risk of being detected. It does, however, fit in perfectly with Judith's self-understanding as a warrior of God. Killing the enemy was not enough - he, or some object symbolizing him, had to be devoted $-\rightarrow$ anathèmato God, in order to really complete her mission.

\subsection{The LORD Almighty Resisted him with Feminine Hands...}

Of course, before Judith dedicates the spoils of her victory to God, she functions as the leader of a procession towards Jerusalem. In the psalm (Jth. 16:1-17) she proclaims during this procession, some of the tentative interpretations that had only been based on implications in the text (such as the sacrificial nature of Judith's prayer, or the self-identification of Judith as warrior of God) are now confirmed.

To greet the victorious soldiers with songs of praise had always been a traditional task for the women of Israel. ${ }^{28}$ In that sense, Judith seems to return here to the conventional female sphere, and to leave the role of 'holy warrior' behind. There are, however, several details that suggest otherwise: the peculiar identification of Judith's own body with the land of Israel (Jth. 16:4), and her reference to sacrifices and burnt offerings (Jth. 16:16). The first seems to suggest a more literal approach to sacrifice, with Judith as both priest and sacrificial

\footnotetext{
26 See, e.g., Lev. 27:28; Num. 21:2; Deut. 13:16-17; 20:17; Josh. 6:18, 21; Judg. 1:17; 1 Sam. 15:3, 8-9.

27 See, e.g., W. K. van der Molen, Een ban om te mijden. Bouwstenen voor een bijbelstheologische verkenning ( $\mathrm{PhD}$ diss, University of Groningen, 2008).

28 Examples range from Miriam (Exod. 15:20-21) to Deborah (Judg. 5) and Jephta's daughter (Judg. 11:34) to the women expressing their admiration for David and contempt for Saul in their songs (1 Sam. 18:6-7).
} 
victim mediating between God and his people, while the latter advocates a more interiorized form of sacrifice.

Judith 16:4 reads:

He [Assur] said to light my borders on fire, and to kill my young men with the sword, and my nursing women he put to the ground, and my little ones he gave up for plunder, and my virgins he despoiled.

There is some uncertainty about the referent of the first person pronouns in this verse. Since Judith is the speaking subject of these words, grammatically, they must refer to her. However, to understand the verse in this way would mean to construe Judith as the 'proprietor' of the borders, young men, nursing women, little ones, and virgins mentioned here. The question then arises who 'owns' all of these individuals. Whose borders are being lit on fire, whose young men killed with the sword? Israel's? Judith's? Judith-as-Israel's? God's? Judithas-God's? The ambiguity remains unresolved. There are certainly instances in which Judith is identified or identifies herself with the people of Bethulia or even Israel as a whole. At other times, however, the text emphasizes the discrepancy between Judith on the one hand and the population of Israel/ Bethulia on the other. Put very briefly, the people are the passive object of Judith's active salvific actions. Perhaps, then, the identification must be sought in a different direction. In fact, Judith seems to occasionally identify herself with the God of Israel, or at least to occupy a middle position between the people and the deity: she feels competent to speak in God's name without having received any explicit instructions from him (for example, Jth. 8:15-37), and she ascribes her actions to him, although he is not otherwise mentioned in the text (for example, Jth. 13:11). I would suggest that the psalm is another instance of Judith identifying herself, at least to some extent, with Israel's God.

Perhaps Judith's self-characterization through her psalm can be construed as an instance of ritualization in the extreme. Through the roles she takes on priest, self-sacrificing holy warrior, savior of her people, and ultimately representative of God - Judith herself gains a sacred quality. One might say that she is an example of what Mauss and Hubert see as the function of sacrifice in general: communication between the profane world of the worshipper and the sacred world of the divine. ${ }^{29}$ Offering her body for the sake of the community, 
Judith becomes this means of communication between God and his people. In the process, she herself is made holy - at least for as long as her sacrificial role lasts, and perhaps even for the rest of her life. After all, her spatial removal from the rest of the community (Jth. 8:5; 16:21) and her refusal to enter into a new marriage (16:22) underline how far removed Judith is from the mundane reality surrounding her.

\subsection{Every Sacrifice is too Small...}

Towards the end of the psalm, Judith makes another noteworthy remark, this time in the direction of a metaphorical or interiorized understanding of sacrifice:

For every sacrifice is (too) small for a sweet fragrance, and every bit of fat falls short as a burnt offering for you; but whoever fears the Lord is great through them all (Jth. 16:16).

What was only implied in the beginning is now put into so many words: sacrifice per se is legitimate, but not enough. It is all about the interiorization of 'fear of the Lord' - a mind-set that Judith personifies. The reader is reminded of passages like 1 Sam 15:22, ${ }^{30}$ where Samuel rebukes Saul for wanting to sacrifice the plunder of the Amalekites instead of destroying it, or Micah 6:6-8, ${ }^{31}$ where Micah confronts the people for their tendency to offer impressive sacrifices instead of obeying God. Protestant theologians have been tempted to read a dismissal of all cultic service in(to) these verses. However, this conclusion seems unwarranted. Neither Judith nor the prophets condemn sacrifice as such. Rather, they insist that it must be accompanied by obedience to God.

\section{4}

\section{Conclusions}

It seems safe to say that through her prayers and the dedication of her acts to God, Judith consistently transfers her sometimes highly dubitable behavior

3o Samuel inquires of Saul: "Does God delight in burnt offerings and sacrifices as much as in obeying God? To obey is better than sacrifice, and to heed is better than the fat of rams" (1 Sam. 15:22).

31 Micah wonders: "Will God be pleased with thousands of rams, with ten thousand rivers of olive oil? Shall I offer my firstborn for my transgression, the fruit of my body for the sin of my soul? He has shown you, o mortal, what is good. And what does God require of you? To act justly and to love mercy and to walk humbly with your God" (Micah 6:7-8). 
(risking her sexual purity, seduction, duplicity, and ultimately murder) into a ritual/religious context. In the Book of Judith as a whole, we find conventional ritual and sacrificial acts side by side with instances of ritualization and internalized or metaphorical sacrifice. The sacrificial practice at the Temple continues despite - and in part because of - the Assyrian threat, and is still observed at the very end of the narrative (Jth. 16:18-19). Simultaneously, Judith engages in, or even invents, alternative practices. Some of these, such as Judith's asceticism and prayers, could be categorized as internalizations of traditional practices appropriate for a woman who, after all, was not allowed to participate in traditional Temple sacrifice. In all cases of alternative sacrifice throughout the book, then, one deviation from conventional practice is the change of the person who performs the sacrifice. In addition, the nature of the object to be offered is altered (fasting and praying come in the place of animal or plant offerings) as well as the location (Judith's roof and the enemy camp instead of the Temple). Perhaps the most radical change is connected with Judith's selfidentification as 'warrior of God', which implies the double role of priest and sacrificial victim.

Considering these alterations in virtually all areas pertaining to the notion of sacrifice, what I have construed as sacrifice in the Book of Judith seems so far removed from the standard practice at the Jerusalem Temple - which was still fully functional at the time Judith was written - that the legitimacy of my reading may well be questioned. Is not the whole notion of 'interiorization' or 'metaphorization' of sacrifice a (post-)modern one, far removed from the ancient author's intellectual horizon? Certainly, this author would not have put the same labels on the actions and attitudes of his protagonist. Nevertheless, in the absence of the Temple, rabbinic Judaism would develop a metaphorized approach to sacrifice, substituting it with elements like prayer, Torah study and fasting. Is it really so far-fetched to detect a similar tendency in the Book of Judith? Perhaps discontented with the standard procedure of Temple sacrifice, the author of Judith may have started looking for alternatives. This is not to imply that the Book of Judith discredits the sacrificial practice at the Temple in general. Throughout the book, much emphasis has been put on the centrality of the holy city and the sanctuary; in fact, it is the "sanctuary and the Temple and the altar" that Judith sets out to rescue (Jth. 8:24).

Nevertheless, there are a few indications that conventional sacrifice was seen as 'necessary but insufficient condition' for proper worship of God. In response to the extensive sacrifices the Israelites offer upon hearing of the Assyrian threat, the narrator recounts that "God heard their [the Israelites'] voices and looked on their misery" (Jth. 4:13). God does not, however, come into action at this point in the narrative - do ut des does not work in this instance, 
perhaps due to the mind-set of the people, which Judith describes as "testing (or blackmailing?) God" (Jth. 11:8). Judith's attitude and actions form a positive contrast: she leads a life of interiorized sacrifice, but does not expect anything in return. She asks God to reveal his power through her, but only in order to "make all your peoples and all the tribes know the knowledge that you are God, the God of all power and might, and that there is no other shielding the people of Israel but you" (Jth. 9:14). ${ }^{32}$ And last but not least, she is willing to become the sacrificial victim herself - an attitude which, perhaps, the author of Judith would find fitting for the people of Israel as a whole.

32 Perhaps it is also significant that Judith is a woman, and therefore excluded from regular Temple sacrifice. It would lead much too far to characterize the author of Judith as a feminist avant la lettre, but he does seem to handle a rather broad definition of who and what qualifies as legitimate sacrifiant and sacrifice. 